\title{
Fluctuations in the Organic Carbon to Chlorophyll a Ratios for Estuarine Benthic Diatom Populations
}

\author{
V. N. de Jonge* \\ Biological Research Ems-Dollard Estuary, Netherlands Institute for Sea Research, Texel, The Netherlands
}

\begin{abstract}
C/Chl-a ratios were determined for benthic diatom populations at 6 stations in the Ems estuary. For mixed field populations previous data are not available. Measurements were carried out over a period of nearly 3 years. The data were statistically analysed. Statistically significant differences in ratio values were indicated within and between years. No indications were found for a statistically significant station effect upon the ratio values. The ratio values over the 3 year period investigated ranged from 10.2 up to 153.9 with yearly averages and standard deviations of $40.3 \pm 13.8 ; 41.2 \pm 20.4$ and $61.4 \pm$ 22.0 , respectively. It was concluded that chlorophyll a measurements in itself are insufficient to describe fluctuations in benthic diatom standing stock. Mechanisms possibly regulating the $\mathrm{C} / \mathrm{Chl}-\mathrm{a}$ ratios are discussed.
\end{abstract}

\section{INTRODUCTION}

The sediments on the bottom of shallow lakes and shallow seas, including their intertidal mud and sand flats, contain variable quantities of micro-algae. It is customary to determine their amount by means of measurements of chlorophyll $a$. In primary production studies, however, biomass increase is normally given in terms of organic carbon. Thus the expression of algal standing stock in terms of organic carbon reflects an appreciable relationship with the primary production process. However, a simple conversion from chlorophyll $a$ to organic carbon is only possible under the assumption that the ratio between both components is more or less constant or that the fluctuations are at least well known. Organic carbon to chlorophyll a ratios for natural benthic diatom populations were not available until now. The published data on organic carbon to chlorophyll a ratios derived from natural phytoplankton populations are variable, scarce and mostly obtained during short bloom periods. Data for well-growing populations are given in Table 1.

Steemann-Nielsen and Hansen (1959), Rodhe et al. (1966), Anderson (1969), Sayo et al. (1969), Takahashi et al. (1972), Eppley et al. (1973) and Fee (1976) suggest the existence of light adaptation by a cell

- Present address: Department of Systematic Botany, State University Groningen, P. O. Box 14,9750 AA Haren, The Netherlands. chlorophyll a increase under low light intensities. Harvey (1953), Brown and Richardson (1968), Beale and Appleman (1971) and Sheridan (1972) found an inverse proportion between light intensity and chlorophyll a concentrations for algal cells. Steele and Baird (1962), Antia et al. (1963), Coombs et al. (1967), Eppley (1968), Strickland et al. (1969), Hobson and Pariser (1971), Thomas and Dodson (1972) and Perry (1976) showed that deficiency of $\mathrm{P}, \mathrm{N}$ and Si could lead to a considerable increase in the organic carbon to chlorophyll a ratios. Caperon and Meyer (1972), Eppley and Renger (1974) and Perry (1976) described a negative correlation between specific growth rate and the organic carbon to chlorophyll a ratio. A list of the data available is given in Table 2 .

All investigations referred to show that chlorophyll a is not necessarily a good and conservative unit to describe the quantity of algal biomass. Further, it is uncertain whether the phytoplankton carbon to

Table 1. C/Chl-a ratios determined for well-growing natural algae populations

\begin{tabular}{|ll|}
\hline Authors & C/Chl-a ratios \\
\hline Parsons \& Strickland (1959) & 39.6 \\
Antia et al. (1963) & 25 \\
Eppley (1968) & $22.2-47.5$ \\
Eppley et al. (1971) & 60 \\
Eppley et al. (1977) & $10-90$ \\
\hline
\end{tabular}

$0171-8630 / 80 / 0002 / 0345 / \$ 02.00$ 
Table 2. Organic carbon to chlorophyll a ratios determined during exponential growth and nutrient limitation of cultures and natural algae populations

\begin{tabular}{|c|c|c|}
\hline Authors & $\mathrm{C} / \mathrm{Chl}-\mathrm{a}$ ratios & Nature of investigated populations \\
\hline Steele \& Baird (1962) & $29.2-714.3$ & Culture of Skeletonema sp. \\
\hline Antia et al. (1963) & $23.5-114$ & Induced bloom; mixture of 6 diatoms and 1 dinoflagellate \\
\hline Coombs et al. (1967) & $23.5-29.6$ & Si-deficiency; Navicula pelliculosa phytoplankton \\
\hline Eppley (1968) & $\begin{array}{l}(22.2-47.5)- \\
(71.4-125.0)\end{array}$ & $\begin{array}{l}\text { No detectable } \mathrm{N}_{\text {; natural population, }} \\
\text { open sea, composition unknown }\end{array}$ \\
\hline Strickland et al. (1969) & $34.5-83.3$ & N limitation; deep tank population of Caclonia niei \\
\hline Hobson \& Pariser (1971) & $14.7-100.0$ & $\mathrm{NO}_{3}$ deficiency; Thalassiosira fluviatilis \\
\hline Caperon \& Meyer (1972) & $55.0-500.0$ & N limitation; chemostat culture of Thalassiosira pseudonana \\
\hline Thomas \& Dodson (1972) & $19.0-61.8$ & N limitation; chemostat culture of Chaetoceras gracilis \\
\hline $\begin{array}{l}\text { Eppley \& Renger (1974) } \\
\text { Perry }(1976)\end{array}$ & $28.6-91.4$ & $\begin{array}{l}\mathrm{N} \text { and P limitation; chemostat culture } \\
\text { of Thalassiosira pseudonana }\end{array}$ \\
\hline
\end{tabular}

chlorophyll a ratios also hold for benthic diatom populations. Therefore, organic carbon to chlorophyll a ratios were determined for intertidal mobile benthic diatom populations. It will be demonstrated that there are clear fluctuations in the organic carbon to chlorophyll a ratios (C/Chl-a) for benthic diatoms and some other micro-algae over the year and between years. Data were collected over about three years at 6 sampling stations in the estuary of the river Ems.

\section{MATERIALS AND METHODS}

\section{Collection and Trapping of Benthic Diatom Populations}

Surface sediment of about $2 \mathrm{~mm}$ thickness, coloured brown by diatoms, was collected from 6 arbitrarily chosen stations in the estuary of the river Ems (Fig. 1). The sediments were scraped off and a volume of about $1 \frac{1}{2}$ I was mixed with some seawater until a very thick and tough slurry was obtained. The slurry was put into a rectangular container $(60 \times 40 \times 12 \mathrm{~cm})$ and spread out to a flat layer. Water present on the sediment surface was removed. The sediment surface was covered with an 0.5 to $1 \mathrm{mu}$ thick layer of flamed and acid washed sand (Merck, No. 7536 or Brocacef ZA 152). Then a monolayer of Whatman's Grade 105 lens tissue $(46 \times 57 \mathrm{~cm})$ was brought lengthwise upon the sediment and was pasted with some water against the container's wall. After this, two other lens tissues were placed together across the former one. The containers were covered with transparent plastic to prevent desiccation and placed for about 16 to $24 \mathrm{~h}$ under conditions of $12{ }^{\circ} \mathrm{C}, 65-80 \mu \mathrm{E} \mathrm{m} \mathrm{m}^{-2} \mathrm{~s}^{-1}$ and a light period of $6-8 \mathrm{~h}$.

\section{Harvesting Procedures}

After at least $16 \mathrm{~h}$ the two upper lens tissues only were carefully removed, torn up in a number of pieces, and put into a beaker partly filled with organic carbon free salt water $\left(30.77 \mathrm{~g} \mathrm{NaCl}, 0.88 \mathrm{KCl}, 1.10 \mathrm{~g} \mathrm{Na}_{2} \mathrm{SO}_{4}\right.$ and $0.20 \mathrm{~g} \mathrm{NaHCO}_{3}$ per litre distilled water, being isotonic with $35 \% \mathrm{~S}$ sea water). The salt water used was diluted to within $5 \% \mathrm{~S}$ with the salinity of the

Fig. 1. Estuary of the river Ems with sampling stations Eemshaven, Hoogwatum, Paap, Reiderplaat, Heringsplaat and Oost Friesche Plaat

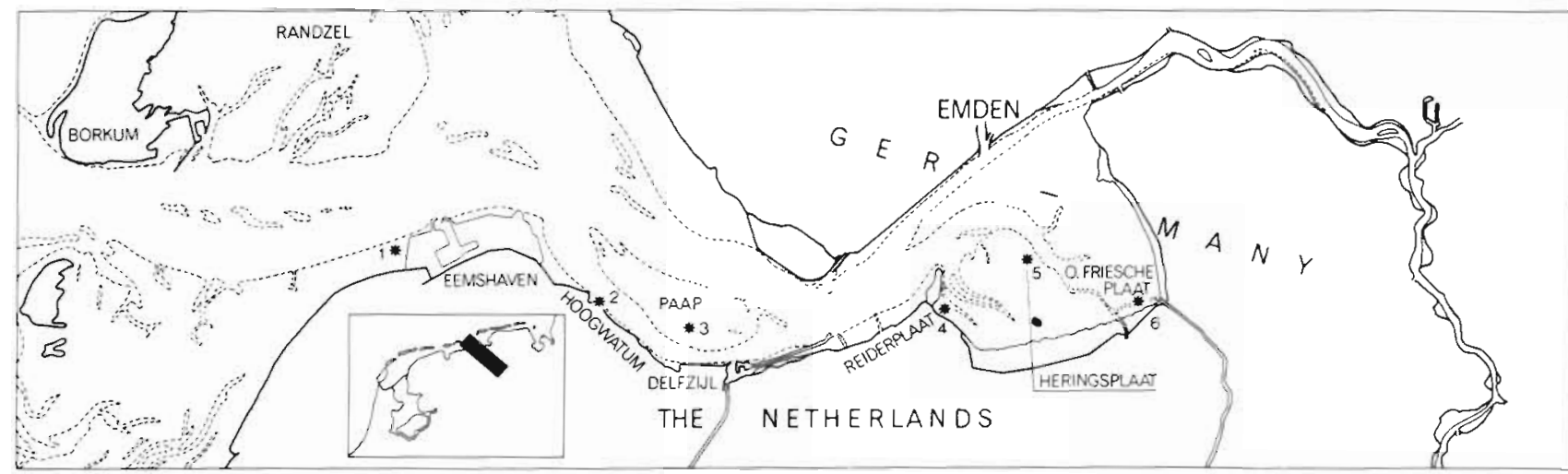


water of the sampling station. After that the beaker was closed and vigorously shaken by hand for about 10 s. The suspension was poured out over three layers of about $2.5 \mathrm{~mm}$ thick foam plastic followed by a $55 \mu \mathrm{m}$ nylon sieve. The lens tissue fibres were separated from the diatoms by the foam plastic barrier. The bulk of harpacticoid copepods were caught by the $55 \mu \mathrm{m}$ sieve. Microscopic inspections affirmed that the clear, light brown-coloured suspension contained only diatoms and nearly no bacteria.

\section{Additional Procedures for Other Algal Groups}

When mixtures of different algal groups and of many protozoa were obtained (e. g. Station Oost Friesche Plaat, Fig. 1), further processing was necessary. These mixtures were separated with a somewhat modified version of the technique described by de Jonge (1979). The procedure followed is based on density gradient centrifugation of the samples in Ludox-TM. Euglena species (Euglenophyceae) could normally be harvested from the $30 \%$ Ludox-TM layer, benthic diatoms (Bacillariophyceae) from the $70 \%$ layer and Merismopedia species (Cyanophyceae) from the $15 \%$ layer.

\section{Determinations}

The suspension obtained was used to determine the C/Chl-a ratio per station (Fig. 1) per date. Samples with a volume between 10 and $25 \mathrm{ml}$ were used for chlorophyll a determination. The sample was put into a centrifuge tube and centrifuged for 5 min at $760 \times \mathrm{g}$ on top of the tubes. The greater part of the supernatant was removed by a pipette connected with a vacuumpump, the remaining sample in the tube frozen $\left(-20^{\circ} \mathrm{C}\right)$, freeze dried and the chlorophyll a content determined according to Lorenzen (1967). Four replicas from the suspension were used for the analysis.

For determination of organic carbon a sample of 100 $\mathrm{ml}$ was used, filtered over Whatman GF/C glass fibre filters under low vacuum and quickly washed with carbon-free salt water to remove possible dissolved organic as well as inorganic carbon. Filters were dried for at least $2 \mathrm{~h}$ at $50^{\circ} \mathrm{C}$, stored in a desiccator and the carbon content determined using a Coleman $\mathrm{C}$ and $\mathrm{H}$ analyzer, Model 33 (Coleman Instruments Inc., Maywood, Illinois, USA). Also for this analysis four replicas were used.

\section{Statistical Methods}

The $\mathrm{k}$ sample test of Kruskal and Wallis (1952) supplemented by the multiple comparison test of Dunn
(1964), the two sample test of Wilcoxon (1945) and the test of Friedman (1937) for testing the agreement between rankings were applied to establish station, season and year effects on $\mathrm{C} / \mathrm{Chl}-\mathrm{a}$ rations.

\section{RESULTS}

\section{Field Observations}

Figure 2 shows the $\mathrm{C} / \mathrm{Chl}$-a ratios obtained over the total period investigated regardless of the sampling station. There are remarkable differences in the values over the period investigated. Also between the stations at about the same sampling date differences are observed. Data obtained from algal groups other than benthic diatoms were scarce. Therefore, it was not possible to analyse them statistically. However, Figure 2 shows that the $\mathrm{C} / \mathrm{Chl}-\mathrm{a}$ ratios obtained for Cyanophyceae such as Merismopedia sp. (mainly Merismopedia

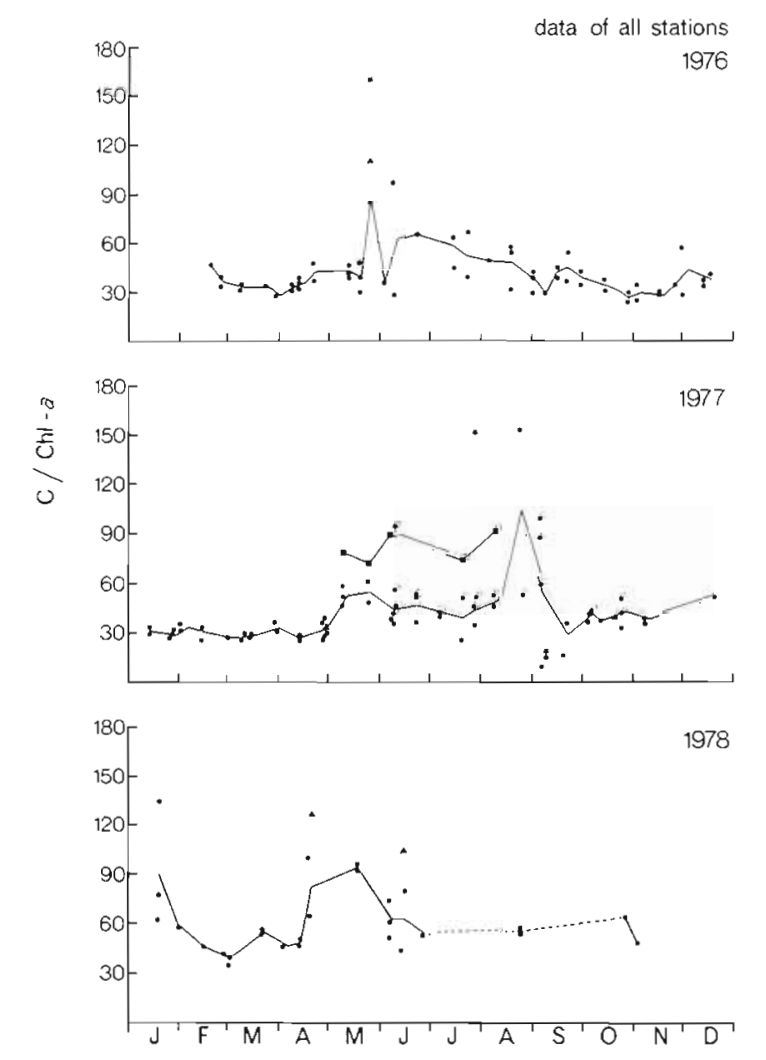

Fig. 2. Organic carbon to chlorophyll a ratios for the 6 stations investigated. Solid and dotted lines: curve based on averages per week (cf. Table 3). The sharp maximum observed in May/ June 1976 is possibly an artefact caused by only a single observation. - Bacillariophyxeae (benthic mobile species); . Merismopedia species; $\Delta$ Euglenophyceae; stars: Cyanophyceae other than Merismopedia species (mainly Oscillatoria species) 
Table 3. C/Chl-a ratios obtained for the stations investigated. n: number of observations; SD: mean and standard deviations of C/ Chl-a ratios per period per station and per period irrespective of station (total). For explanation of station numbers see Figure 1

\begin{tabular}{|c|c|c|c|c|c|c|c|c|c|c|}
\hline Period & No. & Week no. & & 1 & ion no & 3 & 4 & 5 & 6 & Total \\
\hline \multirow[t]{18}{*}{1976} & \multirow[t]{3}{*}{1} & $1-9$ & $n$ & 1 & 0 & 0 & 0 & 1 & 1 & 3 \\
\hline & & & mean & 45.6 & & & & 33.3 & 39.3 & 39.5 \\
\hline & & & $\mathrm{SD}$ & & & & & & & 6.2 \\
\hline & \multirow[t]{3}{*}{2} & $10-17$ & $\mathrm{n}$ & 4 & 2 & 3 & 1 & 1 & 1 & 12 \\
\hline & & & mean & 33.9 & 39.4 & 33.1 & 33.1 & 35.0 & 30.2 & 34.3 \\
\hline & & & $\mathrm{SD}$ & 2.3 & 10.5 & 5.1 & & & & 4.8 \\
\hline & \multirow[t]{3}{*}{3} & $18-25$ & $\mathrm{n}$ & 2 & 3 & 4 & 1 & 1 & 0 & 11 \\
\hline & & & mean & 37.9 & 57.9 & 45.3 & 35.3 & 83.1 & & 49.9 \\
\hline & & & $\mathrm{SD}$ & 11.2 & 33.0 & 15.4 & & & & 22.1 \\
\hline & \multirow[t]{3}{*}{4} & $26-33$ & $\mathrm{n}$ & 2 & 2 & 2 & 1 & 1 & 1 & 9 \\
\hline & & & mean & 47.6 & 39.6 & 59.7 & 65.0 & 63.4 & 44.3 & 51.8 \\
\hline & & & $\mathrm{SD}$ & 13.2 & 12.2 & 8.3 & & & & 12.4 \\
\hline & \multirow[t]{3}{*}{5} & $34-41$ & $\mathrm{n}$ & 4 & 1 & 4 & 1 & 1 & 2 & 13 \\
\hline & & & mean & 38.9 & 29.2 & 38.8 & 28.9 & 38.4 & 41.2 & 37.7 \\
\hline & & & $\mathrm{SD}$ & 3.1 & & 9.9 & & & 4.4 & 6.6 \\
\hline & \multirow[t]{3}{*}{6} & $42-52$ & $\mathrm{n}$ & 3 & 0 & 5 & 1 & 2 & 2 & 13 \\
\hline & & & mean & 30.6 & & 31.5 & 30.3 & 25.8 & 44.7 & 32.4 \\
\hline & & & $\mathrm{SD}$ & 4.8 & & 6.3 & & 2.3 & 16.0 & 8.5 \\
\hline \multirow[t]{18}{*}{1977} & \multirow[t]{3}{*}{1} & $1-9$ & $\mathrm{n}$ & 4 & 0 & 4 & 1 & 1 & 1 & 11 \\
\hline & & & mean & 32.3 & & 28.4 & 31.0 & 26.7 & 28.7 & 29.9 \\
\hline & & & $\mathrm{SD}$ & 3.9 & & 2.4 & & & & 3.3 \\
\hline & \multirow[t]{3}{*}{2} & $10-17$ & $n$ & 4 & 2 & 4 & 2 & 1 & 2 & 15 \\
\hline & & & mean & 28.1 & 28.6 & 32.2 & 29.8 & 38.8 & 27.3 & 30.1 \\
\hline & & & SD & 1.8 & 0.4 & 5.0 & 0.5 & & 2.3 & 4.0 \\
\hline & \multirow[t]{3}{*}{3} & $18-25$ & $\mathrm{n}$ & 3 & 4 & 4 & 1 & 1 & 0 & 13 \\
\hline & & & mean & 46.9 & 46.5 & 49.7 & 47.3 & 56.1 & & 48.3 \\
\hline & & & SD & 8.7 & 9.4 & 9.3 & & & & 8.0 \\
\hline & \multirow[t]{3}{*}{4} & $26-33$ & $\mathrm{n}$ & 0 & 3 & 3 & 1 & 1 & 1 & 9 \\
\hline & & & mean & & 40.2 & 47.0 & 52.0 & 46.8 & 35.2 & 43.9 \\
\hline & & & $\mathrm{SD}$ & & 13.4 & 4.8 & & & & 8.8 \\
\hline & \multirow[t]{3}{*}{5} & $34-41$ & $n$ & 2 & 4 & 3 & 2 & 1 & 0 & $12^{\circ}$ \\
\hline & & & mean & $48.5^{\circ}$ & 53.5 & 54.7 & 27.0 & 15.4 & & $45.4^{\circ}$ \\
\hline & & & SD & $16.8^{\circ}$ & 35.3 & 30.4 & 23.8 & & & $27.9^{\circ}$ \\
\hline & \multirow[t]{3}{*}{6} & $45-52$ & $\mathrm{n}$ & 2 & 1 & 3 & 0 & 0 & 0 & 6 \\
\hline & & & mean & 39.8 & 51.3 & 41.7 & & & & 42.7 \\
\hline & & & SD & 4.2 & & 9.7 & & & & 7.7 \\
\hline \multirow[t]{18}{*}{1978} & 1 & $1-9$ & $\mathrm{n}$ & 2 & 1 & 3 & 1 & $1 \cdots$ & 0 & $8^{\cdots}$ \\
\hline & & & mean & 51.4 & 41.0 & 56.2 & 39.1 & $45.6^{\circ}$ & & $50.4^{\cdots}$ \\
\hline & & & $\mathrm{SD}$ & 14.3 & & 21.0 & & & & 13.9 \\
\hline & 2 & $10-17$ & $\mathrm{n}$ & 1 & 1 & 1 & 1 & 2 & 1 & 7 \\
\hline & & & mean & 50.2 & 45.8 & 99.8 & 45.6 & 58.4 & 55.6 & 59.1 \\
\hline & & & SD & & & & & 7.6 & & 19.0 \\
\hline & 3 & $18-25$ & $\mathrm{n}$ & 2 & 2 & 1 & 1 & 1 & 0 & 7 \\
\hline & & & mean & 82.5 & 78.0 & 51.5 & 43.3 & 79.8 & & 70.8 \\
\hline & & & $\mathrm{SD}$ & 12.9 & 24.7 & & & & & 19.9 \\
\hline & 4 & $26-33$ & $\mathrm{n}$ & 0 & 0 & 1 & 0 & 0 & 0 & 1 \\
\hline & & & mean & & & 52.8 & & & & 52.8 \\
\hline & & & $\mathrm{SD}$ & & & & & & & \\
\hline & 5 & $34-41$ & $\mathrm{n}$ & 1 & 0 & 1 & 0 & 0 & 0 & 2 \\
\hline & & & mean & 56.8 & & 53.7 & & & & 55.3 \\
\hline & & & $\mathrm{SD}$ & & & & & & & 2.2 \\
\hline & 6 & $42-52$ & $n$ & 1 & 0 & 1 & 0 & 0 & 0 & 2 \\
\hline & & & mean & 62.9 & & 47.1 & & & & 55.0 \\
\hline & & & $\mathrm{SD}$ & & & & & & & 11.2 \\
\hline - Withol & tlier: & & & & & & & & & \\
\hline - Withol & & & & & & & & & & \\
\hline
\end{tabular}


glauca f. mediterranea) are rather high as compared with the values obtained for the benthic diatoms. The available data obtained for other groups of Cyanophyceae, mainly consisting of Oscillatoria and Phormidium species, even exceed the values of Merismopedia sp. However, their values are less constant than the values determined for the Merismopedia species, possibly due to changing species composition.

\section{Statistical Analyses}

\section{Analyses Between Stations}

Because the numbers of data obtained from the 6 stations (Fig. 1) were very different and only few for each month, each of the investigated years was divided into 6 periods of approximately equal length. Some variation in the lengths of the periods was introduced in order to reduce the variation in number of data available for each period. Using this procedure further evaluation of the data was possible with distribution free statistical tests.

The test of Kruskal and Wallis was applied to the data of Table 3 (including the two outliers, mentioned at the end of the table) in order to test the hypothesis that the ratios of the 6 stations could be considered as random samples from the same population. Because the numbers of data per station per period were too low to obtain a reliable test result, this test was carried out for combinations of always two successive periods (Table 4). The test could not be applied to weeks number 18-52 of 1978 because of shortage of data. According to the Kruskal-Wallis $\mathrm{k}$ sample test no significant relation could be established between the ratios and the stations where they were obtained. This means that within these pairs of periods no significant differences between the observations from different stations could be established.

An objection against this test is that the stations are compared on the basis of data which are obtained during relatively long time intervals. The most reliable method to establish a pure station effect on C/Chl-a ratios would be a comparison of simultaneous samples from all 6 stations. Such data were not available but 6 relatively short periods could be selected (Table 5) in which for all 6 stations at least one C/Chl-a ratio value was available. If for a station two or more data were available for one such period, the mean value was used. For each of these periods the 6 values obtained were ranked and the concordance between the 6 rankings was tested with Friedman's test. The test result ( $P$ $=0.07$ ) was nearly significant. This means that the possibility of systematic differences in simultaneous $\mathrm{C}$ / Chl-a values between the 6 stations cannot be fully excluded.

Table 4. Significance levels (P) of Kruskal-Wallis test for comparing C/Chl-a ratios of different stations for pairs of successive periods as distinguished in Table 3

\begin{tabular}{|c|c|c|c|c|c|c|c|c|c|}
\hline Years & & 1976 & & & 1977 & & & 1978 & \\
\hline Periods & 1,2 & 3,4 & 5,6 & 1,2 & 3,4 & 5,6 & 1,2 & 3,4 & 5,6 \\
\hline Significance level (P) & 0.98 & 0.61 & 0.33 & 0.82 & 0.61 & 0.57 & 0.51 & - & - \\
\hline
\end{tabular}

Table 5. C/Chl-a ratios obtained within relatively short time intervals for the stations investigated. For station numbers see Figure 1. Agreement between the ranks of stations was calculated with the test of Friedmann

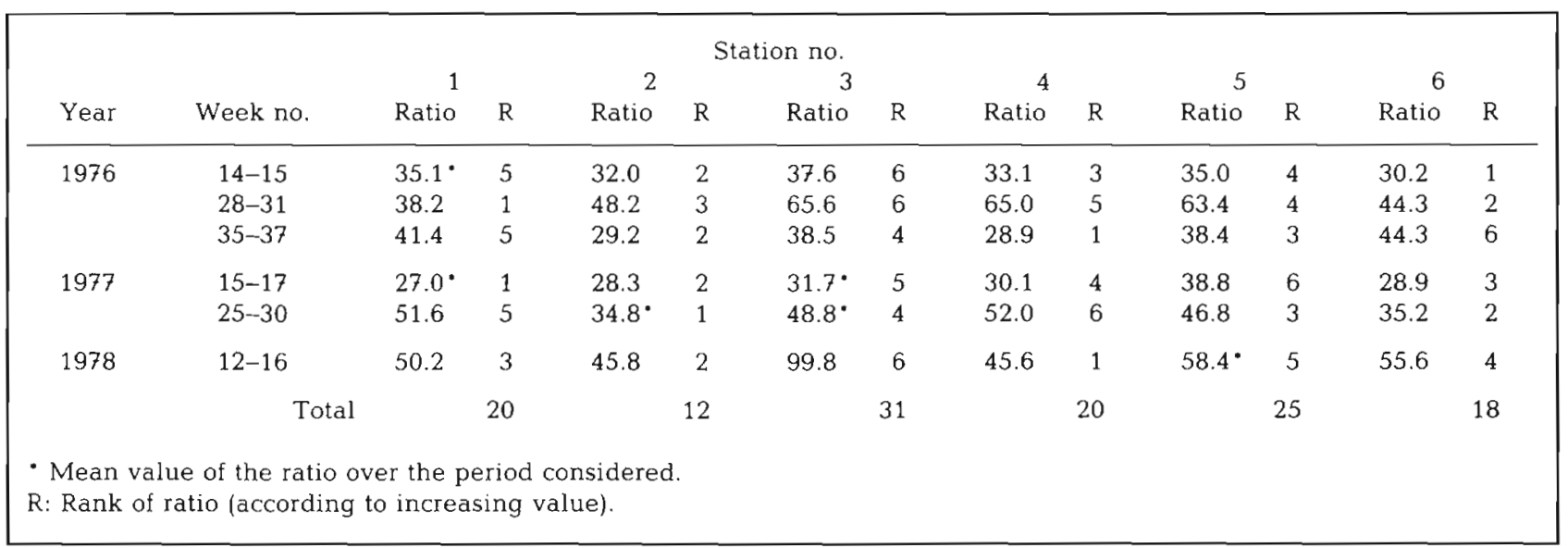




\section{Analyses Between Periods}

The possible station effect as indicated above was neglected in the analyses which were carried out to investigate a period or year effect upon the $\mathrm{C} / \mathrm{Chl}-\mathrm{a}$ ratios. The data of the 6 distinguished periods for 1976 and 1977 (Table 3, including the outliers) were investigated with the test of Kruskal and Wallis (Table 6). For 1978 the test could not be carried out because for the second half of that year too few data were available. Subsequently the periods were compared two by two by means of the simultaneous test of Dunn (1964). Applied at the level $\alpha_{1}$ the probability that any difference between two samples will be significant is at most $\alpha$ under the hypothesis that all samples are drawn from the same population. The results of both tests (Table 6) give evidence of a strong period effect in the $\mathrm{C} / \mathrm{Chl}$-a ratio. These effects, however, are quite different for the two years. In 1976 there is one peak at about the middle of the year (Table 3, Week No. 18-33). In 1977 the values are relatively low at the beginning of the year (Table 3, Week No. 1-17). Thereafter they increase and maintain a relatively high level during 1977 and 1978 (Table 3, 1977 Week No. 18-52 and 1978). By the forementioned shortage of data the high level could not be statistically established for the second half of 1978.

Because of the established period effects the 3 years under consideration were compared separately for each period (including the outliers) by means of the test of Kruskal and Wallis. For the last 3 periods only the years 1976 and 1977 could be compared by means of Wilcoxon's two sample test. The results, summarized in Table 7, are significant for all three periods analysed with the Kruskal-Wallis test and significant only for the last period (Table 3, Week No. 42-52) analysed with the Wilcoxon test. The results of Dunn's test (Table 7) clearly show that the significances obtained in the Kruskal and Wallis test are due to the high $\mathrm{C}$ / Chl-a ratios as measured in 1978 in particular for the first two periods (Table 3, Week No. 1-17). It is remarkable that for the last period (Table 3, Week No. 42-52) the level of the ratio in 1977 is significantly higher than in 1976. At the end of 1977 the level did not decrease as was the case in 1976 (compare results in Table 6).

\section{DISCUSSION}

Tables 1 and 2 give C/Chl-a ratios as published by a number of authors. The values presented in the present paper are mainly within the range of the literature values (Fig. 2) in spite of the fact that all published values were obtained from phytoplankton species. The clear differences in ratio level for the benthic diatoms and other phytobenthos groups (Fig. 2) strongly indicate that biomass fluctuations cannot simply be described in terms of chlorophyll a. It is necessary to discriminate between different phytobenthos groups. This also means that the species composition should always be studied.

The statistical tests which were carried out indicate differences in $\mathrm{C} / \mathrm{Chl}-\mathrm{a}$ ratios within and between years. Further, no station effect could be indicated. Based on these statistical results some remarks can be made and some possible explanations for the fluctuations observed will be given.

Table 6. C/Chl-a ratios obtained in the six periods distinguished (cf. Table 3) compared by means of the tests of Kruskal and Wallis and of Dunn. The periods are arranged in order of increasing mean rank

Year 1976

Period no.

Week no.

$\mathrm{n}$

Mean rank

$$
\begin{gathered}
6 \\
42-52
\end{gathered}
$$

13

17.5

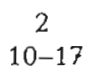

12

23.3

\section{5 \\ $34-41$}

13

31.4
1

$1-9$

3

35.8
3

$18-25$

11

40.1
4

26-33

9

47.4

Test of Kruskal and Wallis: $P<0.001$

Test of Dunn: 6 and $4(P=0.0015) ; 6$ and $3(P=0.028) ; 2$ and $4(P=0.030)$

Year 1977

Period no.

Week no.

12

n Mean rank
$1-9$ 11 17.6

2
$10-17$
15
18.4

$\begin{array}{cc}5 & 4 \\ 35-41 & 26-33 \\ 13 & 9 \\ 39.8 & 42.4\end{array}$

4

Test of Kruskal and Wallis: $\mathrm{P}<0.00001$

Test of Dunn: 1 and $3(P=0.0001) ; 1$ and $4(P=0.069) ; 1$ and $5(P=0.082)$

2 and $3(P=0.0002) ; 2$ and $4(P=0.051) ; 2$ and $5(P=0.056)$ 
Table 7. C/Chl-a ratios of the years 1976, 1977, 1978 compared by means of the test of Kruskal and Wallis or Wilcoxon and Dunn's multiple comparison test

\begin{tabular}{|c|c|c|c|c|c|c|c|c|c|}
\hline & \multirow[t]{2}{*}{ Period } & & \multicolumn{3}{|c|}{ Year } & \multirow{2}{*}{$\begin{array}{l}P \text { (test of } \\
\text { Kruskal \& Wallis } \\
\text { or Wilcoxon) }\end{array}$} & \multicolumn{2}{|c|}{$P$ (test of Dunn) } & \multirow[b]{2}{*}{$77 / 78$} \\
\hline & & & 1976 & 1977 & 1978 & & $76 / 77$ & $76 / 78$ & \\
\hline Period no. & 1 & $\mathrm{n}$ & 3 & 11 & 9 & & & & \\
\hline Week no. & $1-9$ & $\mathrm{R}$ & 14.2 & 6.3 & 18.3 & 0.004 & n.s. & n.s. & 0.0003 \\
\hline Period no. & 2 & $\mathrm{n}$ & 12 & 15 & 7 & & & & \\
\hline Week no. & $10-17$ & $\mathrm{R}$ & 18.4 & 10.6 & 30.7 & $<0.0001$ & n.s. & 0.028 & 0.00003 \\
\hline Period no. & 3 & $\mathrm{n}$ & 11 & 13 & 7 & & & & \\
\hline Week no. & $18-25$ & $\mathrm{R}$ & 12.8 & 14.8 & 23.3 & 0.047 & n.s. & 0.05 & n.s. \\
\hline Period no. & 4 & $\mathrm{n}$ & 9 & 9 & 1 & & & & \\
\hline Week no. & $26-33$ & $\mathrm{R}$ & 11.4 & 7.6 & $-{ }^{*}$ & $0.136^{\prime}$ & & & \\
\hline Period no. & 5 & $\mathrm{n}$ & 13 & 13 & 2 & & & & \\
\hline Week no. & $36-41$ & $\mathrm{R}$ & 12.1 & 14.9 & $-{ }^{*}$ & $0.36^{*}$ & & & \\
\hline Period no. & 6 & $\mathrm{n}$ & 13 & 6 & 2 & & & & \\
\hline Week no. & $42-52$ & $\mathrm{R}$ & 7.8 & 14.8 & $-*$ & $0.012 \cdots$ & & & \\
\hline \multicolumn{10}{|c|}{$\begin{array}{l}\text { R: Mean rank of ratio (according to increasing value) } \\
\text { Year } 1978 \text { not involved in test because of shortage of observations. } \\
\text { n Wilcoxon's two-sample test. } \\
\text { n: Number of observations. } \\
\text { n.s.: Not significant }(P>0.10) \text {. }\end{array}$} \\
\hline
\end{tabular}

\section{Nutrient Deficiency}

Table 2 shows the influence of nutrient deficiency on the $\mathrm{C} / \mathrm{Chl}-\mathrm{a}$ ratio. In nearly all cases there is a reasonable increase in the $\mathrm{C} / \mathrm{Chl}-\mathrm{a}$ ratio caused by a decrease of cell chlorophyll $a$ and increase of cell carbon. Only Eppley and Renger (1974) reported a cell carbon decrease while Thomas and Dodson (1972) found changing cell carbon levels. It is remarkable that the phenomenon of C/Chl-a increase appears regardless of the kind of limiting nutrient. Perry (1976) emphasizes the relation between the influence of nutirent deficiency on the one hand and decreasing growth rate and increasing C/Chl-a ratio on the other hand. Thus an increasing ratio level could indicate a decreasing growth rate due to any kind of nutrient limitation. Because the observations presented in Figure 2 show statistically significant differences in ratio levels for different parts of the year (Table 6). It seems not unlikely to explain this in terms of possible nutrient deficiency. However, unpublished chemical hydrographical data show that nutrient levels in the water of the greater part of the estuary of the river Ems cannot be a limiting factor. The sediment composition on the stations investigated ranges from coarse sandy to fine silty. The organic carbon content as well as the bacterial population density increases with changing sediment composition from sandy to fine silty (Schröder and van Es, in prep.). Parallel to this there is also an increase in mineralisation activity in the sediment, possibly leading to differences in nutrient supply in the top layer. The results given in Tables 4 and 5 lead to the conclusion that no statistically significant station effect upon the C/Chl-a ratios could be indicated. This means that changes in nutrient supply caused by differences in sediment composition and mineralisation activity cannot be a main factor in controlling the $\mathrm{C} /$ Chl-a ratios. If we are still dealing with nutrient deficiency we must think of an influence which is not sitecoupled but algae-layer-coupled. It is not unlikely that in diatom populations nutrient deficiency may appear by a decreased diffusion as a function of diatom density and excreted mucilaginous products such as extra cellular and autolytic products of all kinds of microorganisms (Frankel and Mead, 1973).

The variation in $\mathrm{C} / \mathrm{Chl}-\mathrm{a}$ ratios determined during summer and autumn (Fig. 2) suggests that if deficiency plays an important role, this factor does not influence the ratio levels constantly. This would be not unrealistic because the investigated diatom populations live on relatively unstable sediments which are reworked with changing intensity by wind, tide and benthic fauna.

\section{Species Composition}

The results of Tables 4 and 5 indicate that, in spite of existing gradual differences in species composition along the main axis of the estuary (van den Hoek et al., 1979), this alone cannot be an important factor in 
explaining the changes in $\mathrm{C} / \mathrm{Chl}-\mathrm{a}$ ratios. This might be due to the fact that not only the species composition changes but also the number of individuals per species, smoothing out the species specific ratios.

Another point of importance is that diurnal changes in the $\mathrm{C} / \mathrm{Chl}-\mathrm{a}$ ratio for populations containing one or more benthic diatom species were not studied. This aspect cannot be excluded since for phytoplankton Eppley et al. (1971) observed C/Chl-a ratios with a coefficient of variation of about $20 \%$. Such phenomenon in relation to the very different vertical positions of the stations and thus also different photoperiods might partly explain the variation in $\mathrm{C} / \mathrm{Chl}-\mathrm{a}$ ratios per sampling date.

\section{Abiotic Factors}

A statistically significant effect was indicated for similar periods in successive years (Table 7). This was mainly due to a $50 \%$ increase in the average ratio level for 1978 as compared with the same periods in the previous years. The minimum value was also higher in 1978 as compared with 1976 and 1977 (Table 8). Such a multi-year-coupled factor or combination of factors must be due to still unknown macro-influences.

Table 8. Mean, standard deviation, maximum and minimum values for $\mathrm{C} / \mathrm{Chl}$-a ratios obtained over the periods investigated. For individual data see Figure 2

\begin{tabular}{|lccc|}
\hline & \multicolumn{4}{c}{ Years investigated } \\
Variables & 1976 & 1977 & 1978 \\
\hline Mean & & & \\
Standard deviation & 13.3 & 41.2 & 61.4 \\
Minimum & 20.4 & 22.0 \\
Maximum & 23.6 & 10.2 & 34.7 \\
& 96.0 & 153.9 & 133.1 \\
\hline
\end{tabular}

The absence of a station effect is remarkable because the vertical position of the stations ranged from about $1.1 \mathrm{~m}$ above to about $0.7 \mathrm{~m}$ below mean sea level. Since the mean tidal amplitude in the middle of the estuary is about $2.75 \mathrm{~m}$, this means a difference in immersion time of at least hours per tide. Apparently this is only of little importance to the ratio level. The absence of a station effect means that on the same date different sites in the estuary are directly comparable on the basis of only chlorophyll a measurements. The statistically significant changes in $\mathrm{C} / \mathrm{Chl}$-a ratios for different periods of the year mean that comparison of biomass distributions over periods longer than about a week are not possible on the basis of chlorophyll a determinations alone.

\section{Methodological Remarks}

Some remarks on the method of $\mathrm{C} / \mathrm{Chl}-\mathrm{a}$ ratio determination should be made. Samples were only collected from placed which were light or dark brown coloured by diatoms. This means that there is no information on differences in the C/Chl-a ratio between diatom populations collected from localities with high and very low biomass densities. Another possibly still more important restriction was the fact that from the natural populations only specimens could be harvested which were able to creep into the tissues within the given harvesting period. This certainly resulted in a selection between immobile or less mobile and highly mobile species. Also for the mobile species fraction a possible selection has been made as cells could be in different physiological conditions. It was not possible, however, to develop a rather simple method to isolate all benthic diatom cells quantitatively and alive from sediment. With the density separation method developed earlier (de Jonge, 1979) diatom cells could be quantitatively isolated from inorganic sediments together with part of the organic matter; however, the detritus (organic matter) content of the fractions containing diatoms $(0-70 \%$ Ludox-TM) was too high to make any estimation of the diatom carbon possible. The separation method applied to raw field samples is only suitable for a chlorophyll a determination, diatom identification and counting.

\section{CONCLUSION}

Biomass fluctuations can be described most accurately if $\mathrm{C} / \mathrm{Chl}-\mathrm{a}$ ratios are actually determined. Information on relative biomass distributions by means of chlorophyll a determinations are only possible if samples are taken within a short period. The values given in Table 8 show that the use of a constant ratio (e. g. a yearly average) to convert chlorophyll a to organic carbon may involve errors varying from $34-50 \%$ (overestimation and underestimation, respectively). The actual differences (Table 8 and Fig. 2 maxima and minima) are even greater. The values determined over the 3 years (Table 8) also show that an additional error may be introduced if the yearly average used dates from a previous year.

Acknowledgements. I wish to thank E. Leeuwinga for drawing the figures; Ph. van Elteren (Catholic University, Nijmegen) for statistical advice; Professor Dr. C. den Hartog, Professor Dr. H. F. Linskens (both Catholic University, Nijmegen), Professor Dr. C. van den Hoek (State University, Groningen), Dr. P. de Wolf and my colleagues for critically reading the manuscript. 


\section{LITERATURE CITED}

Anderson, G. C. (1969). Subsurface chlorophyll maximum in the northeast Pacific Ocean. Limnol. Oceanogr. 14: 386-391

Antia, N. J., McAllister, C. D., Parsons, T R., Stephens, K., Strickland, J. D. H. (1963). Further measurements of primary production using a large-volume plastic sphere. Limnol. Oceanogr. 8: 166-183

Beale, S. I., Appleman, D. (1971). Chlorophyll synthesis in Chlorella: regulation by degree of light limitation of growth. Pl. Physiol. 47: 230-235

Brown, T. E., Richardson, F. L. (1968). The effect of growth environment of the physiology of algae light intensity. J. Phycol. 4: 38-54

Caperon, J., Meyer, J. (1972). Nitrogen-limited growth of marine phytoplankton -1 . Changes in population characteristics with steady-state growth rate. Deep Sea Res. 19: $601-618$

Coombs, J., Darley, W. M., Holm-Hansen, O., Volcani, B. E. (1967). Studies on the biochemistry and fine structure of silica shell formation in diatoms. Chemical composition of Navicula pelliculosa during silicon-starvation synchrony Pl. Physiol. 42: 1601-1606

Dunn, O. I. (1964). Multiple comparisons using ranks. Technometrics 6: 241-252

Eaton, J. W., Moss, B. (1966). The estimation of numbers and pigment content in epipelic algal populations. Limnol. Oceanogr. 11: 584-595

Eppley, R. W. (1968). An incubation method for estimating the carbon content of phytoplankton in natural samples. Limnol. Oceanogr. 13: 574-582

Eppley, R. W., Carlucci, A. F., Holm-Hansen, O., Kiefer, D., McCarthy, J. J., Venrick, E., Williams, P. M. (1971). Phytoplankton growth and composition in shipboard cultures supplied with nitrate, ammonium, or urea as the nitrogen source. Limnol. Oceanogr. 16: 741-751

Eppley, R. W., Harrison, W G., Chisholm, S. W., Stewart, E. (1977). Particulate organic matter in surface waters off Southern California and its relationship to phytoplankton. J. Mar. Res. 35: 671-696

Eppley, R. W., Renger, E. H. (1974). Nitrogen assimilation of an oceanic diatom in nitrogen-limited continuous culture. J. Phycol. 10: 15-23

Eppley, R. W., Renger, E. H., Venrick, E. L., Mullin, M. M. (1973). A study of plankton dynamics and nutrient cycling in the central gyre of the north Pacific Ocean. Limnol. Oceanogr. 18: 534-551

Fee, E. J. (1976). The vertical and seasonal distribution of chlorophyll in lakes of the Experimental Lakes Area, northwestern Ontario: Implication for primary production estimates. Limnol. Oceanogr. 21: 767-783

Frankel, L., Mead, D. J. (1973). Mucilaginous matrix of some estuarine sands in Connecticut. J. sedim. Petrol. 43: 1090-1095

Friedman, M. (1937). The use of ranks to avoid the assumption of normality implicit in the analysis of variance. J. Am. statist. Ass. 32: 675-701
Harvey, H. W. (1953). Synthesis of organic nitrogen and chlorophyll by Nitzschia closterium. J. mar. biol. Ass. U. K. 31: $477-487$

Hobson, L. A., Pariser, R. J. (1971). The effect of inorganic nitrogen on macromolecular synthesis by Thalassiosira fluviatilis Hustedt and Cyclotella nana Hustedt grown in batch culture. J. exp. mar Biol. Ecol. 6: 71-78

Hoek, C., van den, Admiraal, W., Colijn, F., de Jonge, V. N. (1979). The role of algae and seagrasses in the ecosystem of the Wadden Sea: A review. In: Wolff, W. J. (ed.) Flora and vegetation of the Wadden Sea; Final report of the Section 'Marine Botany' of the Wadden Sea Working Group. Stichting Veth tot Steun aan Waddenonderzoek, Leiden, pp. 9-118

Jonge, V. N. de (1979). Quantitative separation of benthic diatoms from sediments using density gradient centrifugation in the colloidal silica Ludox-TM. Mar. Biol. 51: 267-278

Kruskal, W. H., Wallis, W. A. (1952). Use of ranks in the onecriterium variance analysis. J. Am. statist. Ass. 47: $583-621$

Lorenzen, C. J. (1967). Determination of chlorophyll and pheo-pigments: spectro-photometric equations. Limnol. Oceanogr. 12: 343-346

Parsons, T. R., Strickland, J. D. H. (1959). Proximate analysis of marine standing crops. Nature, Lond. 184: 2038-2039

Perry, M. J. (1976). Phosphate utilization by an oceanic diatom in phosphorus-limited chemostat culture and in the oligotrophic waters of the central north Pacific. Limnol. Oceanogr. 21: 88-107

Rodhe, W., Hobbie, J. E., Wright, R. T. (1966). Phototrophy and heterotrophy in high mountain lakes. Verh. int. Verein. theor. angew. Limnol. 16: 302-313

Sayo, Y., Iizuka, S., Asaoka, O. (1969). Chlorophyll maximum in Kuroshio and adjacent area. Mar. Biol. 4: 190-196

Schroder, H. G. J., van Es, F. B. (in prep.). Distribution of bacteria in intertidal sediments of the Ems-Dollard Estuary

Sheridan, R. P. (1972). A qualitative and quantitative study of plastoquinone $A$ in two thermophilic blue-green algae. J. Phycol. 8: 47-50

Steele, J. H., Baird, I. E. (1962). Carbon-chlorophyll relations in cultures. Limnol. Oceanogr. 7: 101-102

Steemann-Nielsen, E., Hansen, V. K. (1959). Light adaptation in marine phytoplankton and its interrelation with temperature. Physiologia Pl. 12: 353-370

Strickland, J. D. H., Holm-Hansen, O., Eppley, R. W., Linn, R. J. (1969). The use of a deep tank in plankton ecology. I. Studies of the growth and composition of phytoplankton crops at low nutrient levels. Limnol. Oceanogr. 14: 23-34

Takahashi, M., Satake, K., Nakamoto, N. (1972). Chlorophyll profile and photosynthetic activity in the north and equatorial Pacific Ocean. J. oceanogr. Soc. Japan 28: $27-36$

Thomas, W. H., Dodson, A. N. (1972). On nitrogen deficiency in tropical pacific oceanic phytoplankton. II. Photosynthetic and cellular characteristics of a chemostat-grown diatom. Limnol. Ocenogr. 17: 515-523

Wilcoxon, F. (1945). Individual comparisons by ranking methods. Biometrics 1: 80-83 